\title{
DOCK2 deficiency
}

INSERM

\section{Source}

INSERM. (1999). Orphanet: an online rare disease and orphan drug data base. DOCK2 deficiency. ORPHA:447737

A rare, primary combined $T$ and $B$ cell immunodeficiency characterized by early-onset of recurrent, invasive viral and bacterial infections associated with $\mathrm{T}$ and $\mathrm{B}$ cell lymphopenia, functional defects in T and B cells, poor antibody response and thrombocytopenia. Depending on the type of infectious agent, variable clinical manifestations commonly include recurrent pneumonia, bronchiolitis, otitis media, meningoencephalitis, colitis, and diarrhea, leading to fatal multiorg an failure in severe cases. 